\title{
Refleksja homonimistki po lekturze
}

Radosław Kaleta, Białorusko-polska homonimia międzyjezzkowa, Warszawa, 2014, ss. 169

Pod koniec ubiegłego roku homonimika interlingwistyczna wzbogaciła się o wartościową pozycję naukową zatytułowaną „Białorusko-polska homonimia międzyjęzykowa" autorstwa młodego, acz dojrzałego już badacza, pracownika Katedry Białorutenistyki Uniwersytetu Warszawskiego - Radosława Kalety, uznanego specjalisty w tej dziedzinie. Instytucją sprawczą jest Instytut Slawistyki Polskiej Akademii Nauk - Fundacja Slawistyczna. Monografia otrzymała entuzjastyczne recenzje uznanych językoznawców polskich - Andrzeja Markowskiego i Doroty Urbanek, a także znanego białoruskiego slawisty Genadzia Apanasawicza Cychuna [Генадзь Апанасавіч Цыхун] z Białoruskiej Akademii Nauk. Istotne fragmenty recenzji wydawniczych zamieszczone zostały na czwartej stronie okładki książki.

$\mathrm{Na}$ wstępie należy powiedzieć, iż zainteresowanie językoznawców homonimią międzyjęzykową datuje się od dawna ${ }^{1}$. Obecnie, wraz z rozwojem myśli językoznawczej, rysują się nowe perspektywy badawcze, obejmujące coraz większą paletę języków, także tych odległych. Dotychczas powstało szereg prac dotyczących faktu występowania identyczności/zbieżności ${ }^{2}$ formalnej leksemów bądź wyrażeń przynależnych do różnych systemów językowych jako zjawiska leksykologiczno-translatorskiego, i to w różnych językowych zestawieniach. Prace na ten temat idą w dziesiątki, a może już nawet w setki. Homonimika międzyjęzykowa to temat, po pierwsze, dość popularny, po drugie, niezwykle ważki z punktu widzenia wyzwań współczesnej translatoryki i glottodydaktyki. Słowa cechujące się identycznością/zbieżnością form graficznych w różnych językach jako pierwsi dostrzegli leksykografowie, co wynikało z faktu, iż praktyka leksykograficzna wyprzedzała opis naukowy ${ }^{3}$. Poniżej przedstawiona praca, łącząc teorię z praktyką, z dużym rozmachem wkracza na grunt mało eksplorowanej u nas białorutenistyki.

„Białorusko-polska homonimia międzyjęzykowa” to publikacja wieloaspektowa, splatająca wysoce wyspecjalizowane tematycznie zagadnienia teorii językoznawczych z realnie użytecznym, w pełni funkcjonalnym z punktu widzenia białorusko-polskich zadań translatorskich i glottodydaktycznych, dokonaniem leksykograficznym. Książka zawiera dwie główne, wyraźnie wyodrębnione, ale ściśle współ-

1 O tym K. Wojan, Wstęp do badań wieloznaczności leksemów w ujęciu kontrastywnym, Gdańsk: Wydawnictwo Uniwersytetu Gdańskiego, 2010, s. 268.

2 Relacje paralelizmów polsko-białoruskich pierwszy uwzględnił Jewdokim Romanowicz Romanow w pracy Опьт словаря условных языков Белорусии, с параллелями великорусскими, малорусскими и польскими, wydanej w Wilnie w 1912 roku w Drukarni Syrkina. Zob. m.in. K. Wojan, Wstęp do badań wieloznaczności leksemów w ujęciu kontrastywnym, Wydawnictwo Uniwersytetu Gdańskiego, Gdańsk 2010, s. 272.

3 Prawdopodobnie pierwszym w Europie opracowaniem słownikarskim było dzieło $R e$ marques sur les germanismes: Ouvrage Utile Aux Allemands, Aux Francois, Et Aux Hollandois, $\mathscr{G} c$ saksońskiego romanisty Eléazara de Mauvillona powstałe w Amsterdamie w 1747 roku. 
grające merytorycznie części, przybliżające rodzimemu (i nie tylko) odbiorcy wiedzę na temat homonimiki międzyjęzykowej białorusko-polskiej. Należy podkreślić, iż przedkładana pozycja jest pierwszą w Polsce monografią zjawiska homonimii ujawniającą się w aspekcie dwóch blisko spokrewnionych języków - białoruskiego i polskiego. Istnieje oczywiście kilka mniejszych opracowań tej tematyki, jednak powstały one za granicą, głównie w latach 70. minionego stulecia. Praca Radosława Kalety stała się ważnym ogniwem łączącym białorutenistyczną semantykę leksykalną z leksykografią. Przyjrzyjmy się temu cennemu dziełku.

Omawiana monografia składa się ze wstępu, trzech rozdziałów, zakończenia, indeksu leksemów słownikowych, bibliografii oraz streszczenia angielskojęzycznego. Całość poprzedzona jest krótką notką odautorską, w której autor wyjaśnia, iż zawarte $\mathrm{w}$ oferowanej monografii wyniki dociekań leksykologicznych nawiązują bezpośrednio do jego rozprawy doktorskiej o tym samym tytule, jednak te dwie wersje opracowania nie są tożsame ${ }^{4}$; należy rozumieć, iż przedkładana publikacja stanowi naturalną kontynuacje prac badawczych podjętych w ramach doktoratu. Ponadto autor zwraca się z prośbą do czytelników o przesyłanie mu wszelkich uwag dotyczących opracowania tematu. Świadczy to zarówno o rzetelności naukowej Radosława Kalety, jak i o pokorze, nieczęsto okazywanej przez młode pokolenia dzisiejszych badaczy.

Przed wprowadzeniem do problematyki homonimicznej autor zamieścił wymowny cytat z pracy P.P. Szuby, białoruskiego lingwisty, dziś już klasyka polsko-białoruskiej homonimiki międzyjęzykowej, o treści: Stownik białorusko-polskich $i$ polsko-białoruskich homonimów i paronimów międzyjęzykowych także czeka na swego twórce, a samo zagadnienie - na badacza $a^{5}$. Jest to swego rodzaju zapowiedź konkretnego produktu lingwistycznego (w postaci słownika), wyjaśnienie intencji badawczych, a jednocześnie odsłonięcie celu, do którego wytrwale zmierza Radosław Kaleta, dostrzegając lukę w leksykologii porównawczej relacji języków polski-białoruski, a także realne potrzeby współczesnego językoznawstwa aplikatywnego translatoryki, leksykografii i glottodydaktyki ukierunkowanej zarówno na nauczanie języka białoruskiego w audytorium polskim, jak i polskiego w białoruskim, a nawet można tu byłoby dodać: w znacznie szerszym, wschodniosłowiańskim. Dalej we „Wstępie do rozważań” Radosław Kaleta podkreśla dotkliwy brak większego opracowania na temat zjawiska homonimii międzyjęzykowej dla pary języków: polskiego i białoruskiego oraz brak profesjonalnego narzędzia translatorycznego słownika przekładowego, ilustrującego to zjawisko wąskoaspektowo, a zarazem będącego praktycznym wdrożeniem prowadzonych badań. Suma summarum, młody warszawski białorutenista postanowił wypełnić lukę w piśmiennictwie polskim, i to w pełni mu się udało.

Głównym zadaniem części ogólnoteoretycznej niniejszego opracowania jest wprowadzenie czytelnika w sposób przystępny w problematykę specjalistycznych

4 Rozprawa R. Kalety Białorusko-polska homonimia międzyjęzykowa została przygotowana pod kierunkiem prof. UW dr hab. Niny Barszczewskiej w Uniwersytecie Warszawskim w 2011 roku.

5 R. Kaleta, Białorusko-polska homonimia międzyjęzykowa..., s. 9. 
badań językoznawczych, dzięki którym dokonano w części słownikowej formalno-semantycznej charakterystyki homonimiki leksemowej współczesnego języka białoruskiego. Ponieważ lista haseł słownikowych stanowi autorski dorobek twórcy tejże publikacji, jej autor zapoznaje czytelnika z podstawami naukowymi homonimiki i jej warsztatowymi principiami, jakie legły u podstaw formowania zbioru prezentowanej homonimiki międzyjęzykowej.

Rozdział I „Homonimia wewnątrzjęzykowa na przykładzie języka polskiego i języka białoruskiego (zarys)" podejmuje fundamentalne kwestie definiowania homonimów i homonimii, złożonej terminologii nazewniczej, a także podstawowych rozróżnień homonimii (jej rodzajów). Autor w oparciu o zebraną bogatą literaturę przedmiotu dokonuje zdefiniowania zjawiska homonimii oraz szczególnych bytów homonimów. Stwierdza on arbitralnie, iż homonimia to utożsamienie formalne brzmieniowe i/lub graficzne - co najmniej dwu znaczacych jednostek jezzyka $a^{6}$. Jest to klasyczne, strukturalistyczne ujęcie homonimii, bazujące na kryterium identyczności formalnej (relacja dysjunkcji) i kryterium semantycznym (dyferencjacji znaczeń, czyli relacja alternatywy) jednostek tworzących uporządkowany system językowy. Jednocześnie definicja ta uzmysławia, iż homonimia jest specyficzną relacją form - w płaszczyźnie fonologii i/lub grafemiki, oraz relacją treści - w płaszczyźnie semantyki. Dla poparcia wyrażanych twierdzeń badacz przytacza szereg cytatów literaturowych, zaczerpniętych z prac znanych homonimistów polskich (Małgorzaty Majewskiej, Eugeniusza Grodzińskiego, Katarzyny Wojan i in.), białoruskich (D.M. Karacińskiej i in.) i zachodnioeuropejskich (Johna Lyonsa i in.). W poszczególnych podrozdziałach syntetycznie omawia genologiczny podział homonimiki, tj. homonimię leksykalną, morfologiczną, homoformię, a następnie - wyodrębnione jako podgrupy zjawiska, charakterystyczne dla systemów języków wschodniosłowiańskich - homografię i homofonię. Całość stanowi, ogólnie rzecz biorąc, logiczny wywód na temat złożonej istoty zjawiska homonimii oraz zasadniczej typologii homonimów, przejrzyście ilustrowany przykładami leksemów homonimicznych funkcjonujących w języku białoruskim i polskim. Wprawdzie autor nie wnosi do teorii homonimiki wewnątrzjęzykowej radykalnych rozstrzygnięć, jednak ze znawstwem porządkuje opisywany w różnych pracach (i w odniesieniu do różnorodnych języków) stan wiedzy na temat relacji homonimii mającej przejaw wewnątrz danego systemu językowego. Nowością dla polskiego czytelnika są tu ciekawe przykłady białoruskich leksykalnych zbiorów homonimicznych. Już ich pobieżna analiza nasuwa na myśl zbieżności brzmieniowo-znaczeniowe ze zbiorami homonimicznymi wpisanymi w bratnie języki słowiańskie - polski, rosyjski i inne (np. błrus. $\kappa a c a$ I 'warkocz', II 'osa', III 'mierzeja', por. pol. kosa, ros. koca); ciągi takie mogą z powodzeniem zostać uznane za intersslawizmy (internacjonalizmy słowiańskie) z uwagi na wspólne etymologiczno-historyczne podłoże. Fakt ten może stanowić asumpt do przeprowadzenia dogłębnych, szczegółowych badań leksykalnych w zakresie homonimiki dla konkretnych par języków słowiańskich bądź nawet triad różnych, skoligaconych ze sobą poprzez genetyczne pokrewieństwo, systemów. Radosław Kaleta wzmiankuje na temat przypadków homonimii zdaniowej, będącej częstokroć

6 Tamże, s. 13. 
zarzewiem nieporozumień komunikacyjnych (a nawet poważniejszych konfliktów interpersonalnych czy społecznych), bądź świadomie wykorzystywanym w ludolingwistyce elementem gry językowej. Czytelnik dowiaduje się na przykład, że prosta konstrukcja zdaniowa: Яму трэба пазваніць może mieć dwojaki sens: 1) 'On musi zadzwonić', i 2) 'Do niego trzeba zadzwonić'. Ujawnia się tu specyficzna, znana starożytnym myślicielom, relacja enantiosemii (homoantonimii), szeroko opisana $\mathrm{w}$ literaturze przedmiotu. Podobne konstrukcje gramatyczne spotyka się w polskich gwarach wschodnich i dialektach kresowych, gdzie mamy do czynienia z historyczną interferencją etnolektów słowiańskich będących w bezpośrednim kontakcie geokulturowym z terytorialnymi odmianami polszczyzny (typu Mnie trza/trzeba...). Można zatem mówić o uniwersaliach w homonimice manifestującej się w gramatykach etnolektów wschodniosłowiańskich. Wydaje się, że rzecz jest godna uwagi leksykologów i dialektologów. Oczywiście, w tak krótkim szkicu autor pracy tego nie sygnalizuje, jednak czynienie tu jakiegokolwiek zarzutu nie jest moim zamiarem. Pragnę jedynie wskazać celowość prowadzenia dalszych badań leksykalnych w zakresie homonimiki międzydialektalnej czy międzyetnolektalnej (w aspekcie dialektów przynależnych do różnych języków, najlepiej z językowego pogranicza), które prawdopodobnie dostarczą interesujących wyników o dużej wartości poznawczej, istotnej również z punktu widzenia kulturowo-komunikacyjnego.

W samej rzeczy homonimia syntaktyczna jest szczególnym przypadkiem badań międzyjęzykowych. Zapewne w obszarze konfrontatywnej homonimiki białorusko-polskiej ujawnić można byłoby szereg interesujących casusów typu: Czy może się pan na mnie położyć? (cytat tytułu znanego opracowania leksykograficznego Haliny Bartwickiej i Jolanty Mędelskiej ${ }^{7}$ ).

W drugim rozdziale „Homonimia międzyjęzykowa” na tle zarysowanego syntetycznie merytorycznego ustosunkowania językoznawstwa europejskiego do problemu homonimiki międzyjęzykowej w leksyce z dużą pieczołowitością przybliżony został oryginalny dorobek w obszarze teorii i praktyki, wynikający z badań homonimii i homonimów w językoznawstwie białorutenistycznym. Ta część pracy zawiera syntetyczny i wieloaspektowy opis relacji homonimicznych w przestrzeni interlangue oraz prezentuje odmienne, często ze sobą sprzeczne, podejścia badawcze znanych homonimistów, reprezentujących różne nurty. Kaleta zajmuje się takimi zagadnieniami, jak zróżnicowanie terminologiczno-pojęciowe w różnych szkołach metodologicznych (przytacza różnorodne - nie zawsze jednak równoznaczne - terminy funkcjonujące aż w 14 językach), złożone semantyczne relacje międzyjęzykowe, a mianowicie homonimii i paronimii oraz polisemii międzyjęzykowej. Po rozważaniach teoretycznych o charakterze przeglądowym uczony omawia ważniejsze „gatunki” homonimii międzyjęzykowej, takie jak międzyjęzykowa homonimia wewnętrzna (szkoła homonemiczna K. Wojan, prekursorką była Danuta Buttler), międzyjęzykowa homonimia zewnętrzna (szkoła K. Wojan), międzyjęzykowa homoni-

7 Zob. H. Bartwicka, J. Mędelska, Czy może się pan na mnie położyć? Stowniczek dyferencjalny współczesnego pótnocnokresowego dialektu kulturalnego i języka ogólnopolskiego, Bydgoszcz: Wydawnictwo Uczelniane Wyższej Szkoły Pedagogicznej w Bydgoszczy, 1995. 
mia homo- i heterogeniczna (szkoła Marii Bednarz), pierwszo- i drugostopniowa homonimia międzyjęzykowa (szkoła Danka ` Sipki), dalej rozpatruje homonimy międzyjęzykowe pod kątem ich typologii. Kaleta krótko opisuje różne koncepcje klasyfikacji homonimów międzyjęzykowych czołowych lingwistów europejskich, reprezentujących zarówno szkoły językoznawcze wschodnioeuropejskie, jak i zachodnioeuropejskie. Wymienia propozycje klasyfikacyjne K.M. Gottlieba, Pauliny Stasińskiej, Zygmunta Grosbarta, Katarzyny Wojan, Wołodymira Dubiczyńskiego, P.P. Szuby, Marty Pančikovej, Ryszarda Lipczuka. Konkretny podział homonimów objaśniany jest za pomocą przykładów wywodzących się z reprezentatywnych języków europejskich. Istotnym z metodologicznego punktu widzenia jest ustosunkowanie się do kwestii terminologicznej zbliżonych zjawisk, wikłających komunikację międzyjęzykową, a mianowicie: homonimii międzyjęzykowej i faux amis. Dla autora prezentowanej pracy są to terminy synonimiczne. Podejście takie jest głęboko słuszne, bowiem tradycyjne rezerwowanie tych mian - pierwszego dla lingwistyki, drugiego dla przekładoznawstwa czy glottodydaktyki - wydaje się nieuzasadnione, bowiem $\mathrm{w}$ istocie rzecz dotyczy tych samych zjawisk językowych, związanych z interferencja językową na różnych poziomach systemów. Dalej za Lipczukiem Kaleta wyróżnia i krótko opisuje pięć podstawowych typów międzyjęzykowych relacji semantycznych, ujawniających się w strukturach znaczeniowych par homonimów międzyjęzykowych; są to prywatywność, inkluzja, ekwipolencja, kontraryczność, ekskluzja. Owe relacje będą mieć istotne znaczenie w procesie formowania międzyjęzykowego zbioru homonimów białorusko-polskich. Ich ustalenie jest też punktem wyjścia do leksykograficznego opisu międzyjęzykowych par leksemów homonimicznych.

Kaleta przekrojowo omawia dokonania czołowych badaczy zjawiska homonimii w relacjach polsko-słowiańskich, tj. Marty Pančikovej (polsko-słowackim), Marii Bednarz (polsko-ukraińskim), Zygmunta Grosbarta (rosyjsko-polskim), Pauliny Stasińskiej (polsko-rosyjskim), a także wylicza osiągnięcia leksykografów europejskich, w tym białoruskich, w zakresie homonimiki międzyjęzykowej z komponentem białoruskim. Dokonuje krótkiego chronologicznego przeglądu ważniejszych prac słownikarskich. Żałować tylko należy, że pominął obszerny „Słownik homonimów leksemowych języka rosyjskiego z polskimi ekwiwalentami tłumaczeniowymi” Katarzyny Wojan ${ }^{8}$, w której została utrwalona międzyjęzykowa homonimika rosyjsko-polska. Prawdopodobnie, pracując nad swoim tematem, nie miał jeszcze do tej pozycji dostępu. Nie można jednak powyższego traktować jako uchybienia, bowiem najbardziej spektakularne pozycje słownikarskie zostały w wywodzie uwzględnione. Dane literaturowe zawarte w monografii będą z pewnością solidną pomocą naukową dla młodych adeptów białorutenistyki.

Rozdział trzeci „Analiza białorusko-polskich homonimów międzyjęzykowych” podzielony jest na dwie części. Część pierwsza ma charakter opisu teoretyczno-analitycznego. Drugiej zaś części - realizatorskiej - autor nadał wygodną z punktu widzenia narzędzia pracy i funkcjonalną ze względu na jednoznaczność i zwartość

8 K. Wojan przy udziale E. Skupińskiej-Dybek, Stownik homonimów leksemowych języka rosyjskiego z polskimi ekwiwalentami tłumaczeniowymi, Gdańsk: Wydawnictwo Uniwersytetu Gdańskiego, 2011. 
przekazywanych informacji - formę dwujęzycznego słownika. Już na wstępie uprzedza o trudnościach metodologicznych, sygnalizując różnorodność i wieloaspektowość zjawiska homonimii międzyjęzykowej w odniesieniu do pary języków: polskiego i białoruskiego. Zalicza doń wiele pokrewnych zjawisk międzyjęzykowych, mających umocowanie w różnych płaszczyznach wspólnych dwu odmiennym systemom językowym i analizowanych z różnej perspektywy, a mianowicie: homonimię gramatyczną, homonimię terminów specjalistycznych, homonimię funkcjonalną (międzystylową), homonimię nazewniczą (onomastyczną) związaną z białoruskimi realiami, homonimię słowotwórczą (derywacyjną), homonimię skrótów i skrótowców (abrewiatur), homonimię fonetyczną, homonimię fleksyjną. Badacz wyraża ze wszech miar słuszne - przekonanie, iż każdy z wymienionych rodzajów homonimii wymaga odrębnego prześledzenia i zaprezentowania wyników badań $\mathrm{w}$ formie opracowania naukowego.

Kaleta wprowadza kryterium złudności znaczeniowej sparowanych ze sobą leksemów przynależnych do różnych systemów; posłużenie się nim prowadzi do wyodrębnienia międzyjęzykowych par homonimów całkowitych lub niecałkowitych. Mimo iż główny obiekt analizy klasyfikacyjnej stanowią tu polsko-białoruskie pary homonimów całkowitych, to zbiorom międzyjęzykowym określanym jako niecałkowite autor poświęca także należytą uwagę. Badacz zebrał i przeanalizował 70 par leksemów białoruskich homonimicznych z polskimi, charakteryzujących się zbieżnością co najmniej jednego znaczenia (sensu) i niezbieżnością pozostałych. Wykaz zamieszczonych form homonimów ma porządek alfabetyczny, językiem wyjściowym jest białoruski. Badacz zwraca uwage, iż terminy specjalistyczne typu błrus. $\kappa p b l-$ міналіст i pol. karnista, pol. kryminalista i błrus. крьцмінальнік tworzą odrębny podzbiór homonimiki międzyjęzykowej. Cenny dla polskiego odbiorcy jest wywód autora na temat polskiej normy językowej w odniesieniu do imion białoruskich. Przekład białoruskiego imienia Янкa na polski Janka (a nie: Jan) rozpatruje on w kategorii fałszywego przyjaciela tłumacza, czego konsekwencja jest mylne rozumienie płci danej osoby przez przeciętnego polskiego odbiorcę. Badacz wysuwa interesujący $\mathrm{i}-\mathrm{w}$ mojej ocenie - w pełni uzasadniony postulat ustanowienia dwu równoległych norm językowych: 1) specjalistycznej (profesjonalnej), gdy forma imion będzie zbliżona do białoruskiej (Janka Kupała), stosowanej w tekstach przeznaczonych dla osób zorientowanych w problematyce białorutenistycznej, oraz 2) użytkowej, gdy forma imienia nie będzie pozostawiać wątpliwości polskiemu czytelnikowi (Jan Kupała). Zawarta w rozważaniach sugestia białorutenisty jest istotna z punktu widzenia odbioru przekładu przez rdzennego użytkownika języka polskiego. Zwłaszcza w przypadku naszych najmłodszych, jak się wydaje, generacji, które - wychowane w kontakcie z kulturą globalną, mając mało (bądź wcale nie mając) styczności z językami i etnosami wschodniosłowiańskimi, z którymi przecież łączą nas więzy historyczno-kulturowe - dysponują znikomą wiedzą na ich temat. Propozycję Kalety poparła również w swojej recenzji Dorota Urbanek ${ }^{9}$, która dostrzegła potrzebę spolszczenia imion białoruskich wzorem innych imion obcych, jednocześnie jako doświadczony przekładoznawca wyrażając obawę przed posądzeniem przez środowiska białoruskie o polonizację białoruskich znaczeń pragmatycznych.

9 Cytat odpowiedniego fragmentu z tej recenzji zawarty jest w przypisie 65 książki. 
Sedno rozdziału stanowi użyteczny „Słownik białorusko-polskich międzyjęzykowych homonimów całkowitych". Dokonaniem jest tu bezsprzecznie uformowanie sporego, bo liczącego 170 par międzyjęzykowych leksemów homonimicznych, zbioru wyekstrahowanego z dostępnych słowników przekładowych, wymienionych w tekście przez autora. Badacz wprawdzie od strony teoretyczno-metodologicznej dzieli materiał faktograficzny na dwa zasadnicze rodzaje międzyjęzykowych homonimów leksykalnych: dokładne (błrus. $\underline{\text { 3’g}} 8 a$ i pol. żawa) i przybliżone (błrus.

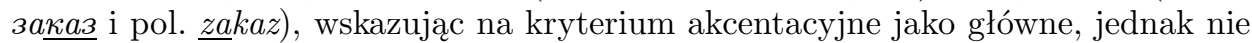
opisuje kryteriów klasyfikacji formalnej, na których się oparł dokonując ekscerpcji z leksykografii zbiorów leksemów jednego języka (J1) wchodzących w relacje homonimii ze zbiorami leksemów drugiego (J2). Zabrakło tu przedstawienia zasad klasyfikacji formalnej par (zbiorów) homonimów międzyjęzykowych. Dla leksemów funkcjonujących wewnątrz systemu językowego decydujące jest - jak wiadomo - kryterium identyczności fonetyczno-graficznej; dla zbiorów konfrontowanych w przestrzeni interlangue należałoby je precyzyjnie określić. W przypadku języków operujących odmiennymi zasadami notacji, tj. polskiego, opartego na alfabecie łacińskim, i białoruskiego, zapisywanego cyrylicą, nie może być przecież mowy o identyczności/zbieżności na poziomie grafii. A zatem warunek tożsamości graficznej ex definitione nie będzie spełniony. Sama akcentuacja (tak jak i pozostałe elementy prozodii właściwej dla każdego z analizowanych języków) nie powinna, moim zdaniem, wpływać na arbitralny podział homonimów międzyjęzykowych na dokładne i przybliżone, bowiem tak naprawdę leksemy należące do odmiennych systemów językowych, a kwalifikowane pod względem formalnym z konieczności jako zbieżne, nigdy nie będac - i nie mogac być - dokładne, jak chce badacz. Piszacca te słowa jest również akustykiem mowy, którego przedmiotem badań był niegdyś cyfrowy obraz akustyczny homonimu języka etnicznego jako elementu wejściowego klasyfikacji formalnej homonimii międzyjęzykowej ${ }^{10}$. Można sądzić, że Radosław Kaleta kryteria i zasady klasyfikacji formalnej omówił szerzej w swej rozprawie doktorskiej bądź innych publikacjach, jednak odniesienia do nich w przypisach nie znajduję.

Autor słownika informuje również, iż zbiór leksykalny wyselekcjonował w oparciu o kryterium synchroniczne; diachronii języka nie brał tu pod uwagę. Oczywiście jest to słuszne stanowisko badawcze, podejście diachroniczne nie jest dla przeprowadzonej konfrontacji istotne.

Budowa artykułu hasłowego białorusko-polskiej pary homonimicznej w zamieszczonym słowniku ma oryginalny, przejrzysty układ tabelaryczny. Lemmy, reprezentowane przez leksemy białoruskie (określmy je jako homonimy J1), są usystematyzowane według alfabetu cyrylickiego w części lewej. Charakterystyka gramatyczna postaci kanonicznej leksemu J1 uwzględnia jedynie akcentuację. Po lemmie, w części środkowej, podane jest jedynie jej zbieżne znaczenie z polskim leksemem (Co oznacza), prawa stronę zaś wypełnia - graficznie przekreślony - polski leksem (homonim J2), przez autora słownika nazwany homonimem międzyjęzykowym,

10 Zob. np. K. Wojan, Z. Wojan, Analiza akustyczna jako parametr klasyfikacji formalnej homonimii międzyjęzykowej, [w:] XLIX Otwarte Seminarium z Akustyki OSA'2002, Polskie Towarzystwo Akustyczne, Oddział Warszawski, Warszawa - Stare Jabłonki 9-13.09.2002, s. 355-361. 
a będący $\mathrm{w}$ istocie pseudoekwiwalentem międzyjęzykowym, którego opis semantyczny sprowadza się jedynie do esencjonalnego podania w nawiasie odpowiednika/odpowiedników białoruskojęzycznego/białoruskojęzycznych (Czego nie ozna$c z a$, np. pol. sutki i odpowiednik błrus. cacki). Artykuły hasłowe ilustrowane są przykładami zdań bądź zaczerpniętych z konkretnego korpusu tekstów, bądź ułożonych na potrzeby publikacji przez autora. Cennym elementem opracowania są właśnie owe dwujęzyczne ilustracje zdaniowe, których mozolnego tłumaczenia podjął się autor. Stanowią one dobry kontekst znaczeniowy dla „kontrowersyjnych” leksemów, kwalifikowanych jako homonimy międzyjęzykowe. Z formalnego punktu widzenia dodałabym jednak, że jednostki określane przez autora jako leksemy białoruskie są w zdecydowanej relacji homonimii z jednostkami leksykalnymi polskimi, które (i tylko te) nazywa homonimami międzyjęzykowymi. Skoro te pierwsze są $\mathrm{w}$ relacji homonimii, to mają również status homonimów międzyjęzykowych. A zatem i leksemy białoruskie, i leksemy polskie są homonimami w płaszczyźnie interlangue.

Dlaczego taka postać hasłowania słownikowego? Przekreślony złudny odpowiednik polski? Autor wyjaśnia, iż wykorzystał „automatyzm” postrzegania formy graficznej znaku języka obcego, polegający na podświadomym, mimowolnym odnoszeniu jej do formy funkcjonującej w języku ojczystym. A zatem w założeniu słownikarza decydującą rolę odgrywają tu pewne funkcje myślowe, polegające na skojarzeniu elementów i wykryciu formalno-treściowych związków między nimi. Celem jest wyrobienie u użytkownika słownika nawyku swoistej językowej nieufności. Słownikarz ma do odbiorcy podejście psychologiczne, w pewnym sensie manipulacyjne, zastawia na niego zręczną pułapkę komunikacyjną (w języku przekładu), by zaraz naprowadzić go na właściwy tok myślenia. Wchodzi w rolę dydaktyka. Chce, by odbiorca sam dostrzegł własny błąd, by poprawił sam siebie, by nie ufał własnej (natywnej?) intuicji językowej, by nauczył się bycia czujnym, by miał świadomość, iż czyhają na niego fałszywi przyjaciele tłumacza. Leksykograf na swój sposób steruje jego myśleniem, ingerując w pamięć (memoryzację) i wnioskowanie. Wcześniej Kaleta przedstawił różne możliwości graficznego konstruowania artykułów hasłowych w słowniku dyferencjalnym. Wybrał model „automatyzujaccy”.

Zastosowana w słowniku metoda objaśniania znaczenia jest niewątpliwie dobra z punktu widzenia współczesnej glottodydaktyki, zwłaszcza ukierunkowanej na nauczanie młodszych pokoleń, przyzwyczajonych do różnego typu wizualizacji przekazywanych treści i nastawionych na tzw. kreatywność myślenia. Forma słownika jest klarowna i przystępna dla osoby uczącej się języka białoruskiego i posiadającej kompetencję języka polskiego. Jest to słownik dydaktyczny, prosty w przekazie, konkretny, pozbawiony elementów akcesorycznych. Z pewnością będzie nieocenioną pomocą w akwizycji języka białoruskiego w szerszym audytorium (także tym konstytuowanym przez nie-Polaków).

Trzeba powiedzieć, iż Radosław Kaleta posiada już bogaty dorobek w zakresie badania zjawiska homonimii białoruskiej i polsko-białoruskiej; wyniki swych analitycznych i konfrontatywnych badań, a także rozważania teoretyczno-metodologiczne zawarł w licznych artykułach naukowych publikowanych na łamach znanych czasopism slawistycznych, tomach zbiorowych i in. Warto tu podkreślić, iż zjawisko homonimii należy do najtrudniejszych kwestii w językoznawstwie, wiąże się bowiem 
z fundamentalnymi problemami językoznawczymi, takimi jak znak, forma, znaczenie, niejednoznaczność, język, system. Radosław Kaleta znakomicie sobie poradził z postawionym zadaniem. Badacz wykazał się filologiczną dociekliwością i skrupulatnością. Omówiona monografia stanowi synteze złożonego zjawiska homonimii, wnosi do teorii i praktyki polskiej białorutenistyki należyte uporządkowanie trudnych zagadnień. Ponadto ma wymiar praktyczny - posiada długo oczekiwaną przez polskiego odbiorcę aplikację w postaci aktualnego słownika dwujęzycznego.

Na uwagę zasługuje również ciekawa okładka autorstwa Ekateriny Kalety. Wizerunek prostej wagi z przechyloną szalą - zobrazowanie niezrównoważenia semantycznych własności homonimicznych leksemów białoruskich i polskich - oraz matematyczny zapis faktów językowych w postaci nierówności różnojęzycznych wyrażeń w tle stanowią trafną metaforę złożonego fenomenu interlingwistycznego, intrygującego badaczy do stuleci.

Książka ukazała się w roku rocznicowym, na 60-lecie Instytutu Slawistyki PAN. Tym bardziej należy się cieszyć z takiego wyróżnienia, bowiem dołączyła ona do grona pozycji naukowych rekomendowanych właśnie przez tę czołową instytucję krajową.

Katarzyna Wojan Gdansk

\section{У вянок памячі Сакрата Яновіча}

Sokrat Janowicz - pisarz transgraniczny. Studia, wspomnienia, materiaty, pod red. G. Charytoniuk-Michej, K. Sawickiej-Mierzyńskiej, D. Zawadzkiej, Białystok 2014 , ss. 520

Сакрат Яновіч (1936-2013) - беларуска-польскі пісьменнік, публіцыст, перакладчык, а таксама культурны дзеяч, палітык, маральны лідэр нацыянальнага руху на Беласточчыне. Ва ўсіх гэтых сваіх амплуа ён меў бясспрэчныя дасягненні, якія цаніліся польскім культурным і навуковым асяроддзем.

У прыгожае пісьменства С. Яновіч прыйшоў у другой палове XX стагоддзя на хвалі узздыму беларускага культурнага, асветніцкага руху. Яго літаратурным дэбютам стала апавяданне "Гнілое ӱ здаровым", надрукаванае $\breve{y} 1956$ годзе беларускім штотыднёвікам "Ніва". У 1969 годзе пабачыў свет зборнік лірычных замалёвак, дзённікавых запісаў і апавяданняў С. Яновіча "Загоны" - першая у беларускім літаб'яднанні "Белавежа" кніга прозы. Творчая спадчына С. Яновіча налічвае каля трыццаці кніг ("Сярэбраны яздок" (1978), "Самасей" (1992), “Доўгая смерць Крынак" (1993), “Дзённік. 1987-1995" (1997) і інш.). Польскаму чытачу вядомыя найперш польскамоўныя выданні: "Беларусь, Беларусь" (1987), "Даліна поўная лёсу" (1993), "Тэра інкогніта: Беларусь" (1993), а таксама пераклады з беларускай: "Вялікі горад Беласток" (1973), "Забыцці" (1978), "Сцяна" (1979), "Самасей" (1981). У 1971 годзе адным з першых "белавежцаў", шматгадовы журналіст бела- 